\title{
Efficiency Improvement Using Bis(trifluoromethane) Sulfonamide Lithium Salt as Chemical Additive in Porphyrin Based Organic Solar Cells
}

Susana Arrechea ${ }^{\mathrm{a}, \mathrm{b}}$, Ana Aljarilla ${ }^{\mathrm{a}}$, Pilar de la Cruz ${ }^{\mathrm{a}}$, Emilio Palomares ${ }^{\mathrm{c}, \mathrm{d} *}$, Ganesh D. Sharma ${ }^{\mathrm{e}^{*}}$, Fernando Langa $\mathrm{a}^{*}$

${ }^{a}$ Universidad de Castilla-La Mancha, Institute of Nanoscience, Nanotechnology and Molecular Materials (INAMOL), Campus de la Fábrica de Armas, 45071-Toledo, Spain. Tel: 349252 68843. E-mail: Fernando.Langa@uclm.es

b Escuela de Ingeniería Química, Facultad de Ingeniería, Universidad de San Carlos de Guatemala. Guatemala.

${ }^{c}$ Institute of Chemical Research of Catalonia (ICIQ), The Barcelona Institute of Science and Technology, Avda. Països Catalans, 14, Tarragona, E-43007, Spain. E-mail: epalomares@ICIQ.ES epalomares@ICIQ.ES

${ }^{\mathrm{e}}$ ICREA, Passeig Lluis Companys, 23, Barcelona. E-08010. Spain.

${ }^{\mathrm{e}}$ Department of Physics, The LNM Institute of Information Technology (Deemed University), Rupa ki Nagal, Jamdoli, Jaipur (Raj.) 302031, India, E-mail: gdsharma273@ @mail.com

\begin{abstract}
Two new conjugated acceptor- $\pi$-donor- $\pi$-acceptor (A- $\pi$-D- $\pi$-A) porphyrins have been synthesised using 3-ethylrhodanine (1a) or dicyanovinylene (1b) groups as acceptor units. Their optical and electrochemical properties made these materials excellent electron donor along $\mathrm{PC}_{71} \mathrm{BM}$ as acceptor for solution-processed bulk heterojunction organic solar cells. The devices based on 1a: $\mathrm{PC}_{71} \mathrm{BM}$ (1:2) and $\mathbf{1 b}: \mathrm{PC}_{71} \mathrm{BM}$ (1:2) processed with $\mathrm{CB}$ showed low power conversion efficiencies (PCE) of $2.30 \%$ and $2.80 \%$, respectively. Nonetheless, after processing the active layer using a mixture of $3 \mathrm{v} \%$ of pyridine additive in THF, the PCE was enhanced up to $5.14 \%$ and $6.06 \%$ for $1 \mathrm{a}: \mathrm{PC}_{71} \mathrm{BM}$ and $\mathbf{1 b}: \mathrm{PC}_{71} \mathrm{BM}$, respectively. Moreover, when we used LiTFSI as chemical additive in pyridine/CB-processed $\mathbf{1 b}: \mathrm{PC}_{71} \mathrm{BM}$ an excellent PCE of $7.63 \%$ was recorded. The effects over the film morphology and the device characteristics (Jsc, Voc and FF) by the introduction of LiTFSI are discussed.
\end{abstract}

Keywords: Photovoltaics, bulk heterojunction solar cells, small molecule, porphyrin.

*Corresponding authors 


\section{Introduction}

Organic solar cells (OSCs) with an interpenetrated network of donor-acceptor domains (so called bulk-heterojunction) [1] offer a fresh perspective in solar energy conversion devices. Fuelled by the success of OSCs based on the active layers consists of low bandgap conjugated polymers as electron donor and fullerene derivatives as electron acceptor with outstanding PCE more than $10 \%$ [2]. -Small molecule (SM) donors have also been intensively investigated too. The small molecule may be seen as complementary alternative to polymers due to their advantages of monodispersity, simple synthesis, high purity and easier control of energy levels [3]. The solution-processed BHJ OSCs have achieved PCE values of 10\% [4] and 13.2\% [5] for single junction and triple junction solar cells, respectively. Such record efficiencies indicate that small molecules may be a strong alternative to conjugated polymers as donors for organic solar cells.

Porphyrins and their derivatives have been extensively investigated for many years in the field of photochemical and biological applications [6]. Porphyrins are derived from the chlorophylls that are crucial to the natural photosynthetic processes in green plants and they are more stable and synthetically easier to obtain than chlorophylls [7]. Porphyrins contain an extended two-dimensional $\pi$-conjugated system suitable for light-harvesting and efficient electron transfer [8]. Moreover, these molecules, exhibit large molar extinction coefficients [9], and their electrochemical and photophysical properties can be change via the central metal modification and/or the introduction of suitable substituents at the peripheral positions of the macrocycle [10]. As a consequence of these outstanding properties, molecules based on porphyrins have been successfully used as sensitizers in dye-sensitized solar cells (DSSC) and PCE values higher than $13 \%$ have been achieved [11]. Finally, due to the thickness limitation imposed to obtain good carrier extraction, molecules with outstanding light absorption are must; thus, it is clear that porphyrins are an attractive target for OSCs and the application of porphyrin derivatives as donors in solution-processed BHJ organic solar cells has attracted significant interest in recent years, with PCEs from 2 to $9.06 \%$ obtained [12].

We report here the synthesis, photophysical and electrochemical properties of two new conjugated A- $\pi$-D- $\pi$-A systems with a Zn-porphyrin as a donor (D), linked by ethynylene bridges to thienylenevinylenethiophene and capped by 3-ethylrhodanine (1a) or dicyanovinylene (1b) groups as acceptor units (Scheme 1). On the other hand, the use of the ethynylene units makes the system planar, and the thienylenevinylene oligomers, act as excellent molecular wires [13] to extend the $\pi$-conjugation. Finally, the incorporation of hexyl chains on the thiophene units to enhance the molecule solubility. We have used these two 
porphyrins as donor along with $\mathrm{PC}_{71} \mathrm{BM}$ as electron donor for the fabrication of solution processed BHJ OSCs. After the optimization of the morphology of the active layer with pyridine additive in chloroform solution, the devices based on $\mathbf{1 a}$ and $\mathbf{1 b}$ as donor showed over all PCE of $5.14 \%$ and $6.06 \%$, respectively. Additionally, the device based on optimized 1b: $\mathrm{PC}_{71} \mathrm{BM}$ active layer improved up to $7.63 \%$, Li-TFSI as chemical additive used.

\section{Experimental}

The synthetic details for the preparation of $\mathbf{1 a}$ and $\mathbf{1 b}$ and their spectroscopic characterization are described in the supplementary information.

\section{Device fabrication and characterization}

Organic solar cells were fabricated using the conventional architecture for ITO/PEDOT:PSS/1a or $\mathbf{1 b}: \mathrm{PC}_{71} \mathrm{BM} / \mathrm{Al}$. Indium tin oxide (ITO) coated glass substrates were cleaned sequentially by 10 minutes ultrasonication in detergent, deionised water, acetone and isopropyl alcohol followed by drying in a nitrogen flow. The substrates were further dried in ambient conditions. PEDOT:PSS solution was filtered and spin coated onto the pre-cleaned ITO substrates at $3500 \mathrm{rpm}$ for $30 \mathrm{~s}$ and then annealed at $120^{\circ} \mathrm{C}$ for 10 minutes. The blends of 1a or $\mathbf{1 b}$ and $\mathrm{PC}_{71} \mathrm{BM}$ (different weight ratios of donor and $\mathrm{PC} 71 \mathrm{BM}$, total concentration 16 $\mathrm{mg} / \mathrm{mL}$ ) were dissolved in chlorobenzene and pyridine (different volume concentration)/chlorobenzene. The solutions were spin coated on top of the PEDOT:PSS layer at $2000 \mathrm{rpm}$ for $60 \mathrm{~s}$ and the samples were dried in a vacuum oven at $40{ }^{\circ} \mathrm{C}$. Finally, the aluminium $(\mathrm{Al})$ electrode was deposited on top of the active layer by thermal evaporation under a vacuum of $10^{-5}$ Torr. In order to deposit the interlayer between the active layer and $\mathrm{Al}$ electrode, bis(trifluoromethane)sulfonimide lithium salt (Li-TFSI) purchased from SigmaAldrich was dissolved in methanol $(5 \mathrm{mg} / \mathrm{mL})$ and then spin coated at $4500 \mathrm{rpm}$ on top of active layer prior to the deposition of the final $\mathrm{Al}$ electrode.

The current-voltage characteristics of the devices were measured using a computercontrolled Keithley 2400 source meter under stimulated AM1.5 G at an intensity of 100 $\mathrm{mW} / \mathrm{cm}^{2}$ provided by a solar simulator. The incident photon to current efficiency (IPCE) of the devices was measured by illuminating the device through the light source and the monochromator and the resulting current was measured using a Keithley electrometer under short circuit conditions.

The hole mobilities of the active layers were determined by fitting the dark current to the model of space charge limited current (SCLC) in the hole only device with the configuration ITO/PEDOT:PSS/active layer/Au. The active layers were deposited under the same conditions as for the corresponding solar cells. 


\section{Results and discussion}

\section{Synthesis and characterization}

The synthesis of the target compounds 1a-b began with a double deprotection of the terminal triple bonds of Zn-porphyrin 2 [14] (Scheme 2) by treatment with TBAF. Water was then added to quench the reaction and the product was extracted with $\mathrm{CHCl}_{3}$. The product was used in the following step without further purification. Zn-porphyrin 4 was obtained in $51 \%$ yield by reaction of deprotected Zn-porphyrin and iodoaldehyde $\mathbf{3}$ under Pd-catalyzed copperfree Sonogashira coupling conditions, using triphenylarsine and $\operatorname{Pd}_{2}(\mathrm{dba})_{3}$ as catalyst [15]. Finally, the target compounds 1a-b were obtained in 59\% and $73 \%$ yield, respectively, by double Knoevenagel condensation reaction of $\mathbf{4}$ with 3-ethylrhodanine and piperidine as base for 1a, and malononitrile and $\mathrm{Et}_{3} \mathrm{~N}$ as base for $\mathbf{1 b}$ (see Supporting Information).

All new compounds were satisfactorily characterized by ${ }^{1} \mathrm{H}$ and ${ }^{13} \mathrm{C}$ NMR, FT-IR and MALDI-TOF MS. Mass spectrometry of $\mathbf{1 a}$ and $\mathbf{1 b}$ confirmed the molecular structures showing the molecular ions at 2367 and 2177 amu, respectively (see Supporting Information for synthetic details and full analytical and spectroscopic characterization). The ${ }^{1} \mathrm{H}-\mathrm{NMR}$ spectra of $\mathbf{1 a}$ and $\mathbf{1 b}$ show the vinylic proton peak at 7.97 and $7.80 \mathrm{ppm}$, respectively, indicating a successful condensation.

Thermogravimetric analysis (TGA) showed decomposition temperatures $\left(\mathrm{T}_{\mathrm{d}}\right)$ of $372{ }^{\circ} \mathrm{C}$ and $387^{\circ} \mathbf{C}$ for $\mathbf{1 a}$ and $\mathbf{1 b}$, respectively, suggesting that $\mathbf{1 a}$ and $\mathbf{1 b}$ have good thermal stability for photovoltaic applications (see Supporting Information, Fig. S13). The melting point of both 1a and $\mathbf{1 b}$ is higher than $300{ }^{\circ} \mathrm{C}$.

\section{Optical properties}

The optical properties of $\mathbf{1 a}$ and $\mathbf{1 b}$ measured in $\mathrm{CH}_{2} \mathrm{Cl}_{2}$ solutions are shown in Figure 1 and the data are listed in Table 1 (also see Supporting Information, Figures S14 and S15). The absorption spectra of 1a and 1b show a panchromatic absorption up to 770-780 $\mathrm{nm}$ with high absorption coefficient values (see Table 1); a red-shift of the main bands, in comparison with the precursor aldehyde 4, was observed. The broad band at $714 \mathrm{~nm}$ is attributed to an intramolecular charge transfer (ICT) process as a consequence of the push-pull effect after the incorporation of the strong electron acceptor moieties 3-ethylrhodanine or dicyanovinylene.

When the absorption spectra were recorded in thin films (as shown in Figure 1), the maximum absorption of both porphyrins (1a and 1b) was red-shifted and broader with respect to those obtained in solution. This effect is attributed to an intermolecular $\pi-\pi$ interaction that leads to an ordered molecular packing in the solid state, thus favouring high charge mobility. The more pronounced red-shift observed for $\mathbf{1 b}$, when compared to $\mathbf{1 a}$, can be attributed to the 
stronger intermolecular interaction due to the DCV groups, which can interact with both the protons of the alkyl chain and the sulfur atoms of the thiophene rings [16] and the nitrogen atom of the DCV can be coordinated with the $\mathrm{Zn}$ atom of the porphyrin core [17]. Finally, the optical bandgap $\left(E_{g}^{\text {opt }}\right)$ was calculated from the onset wavelength $\left(\lambda_{\text {onset }}\right)$ of the absorption spectra in thin films using $E_{g}^{o p t}=1240 / \lambda_{\text {onset }}(\mathrm{eV})$, with values of 1.54 and $1.48 \mathrm{eV}$ for $\mathbf{1 a}$ and 1b, respectively.

\section{Electrochemical properties and energy levels}

The electrochemical properties of $\mathbf{1 a}$ and $\mathbf{1 b}$ were investigated in $o$-DCB/acetonitrile (4:1) as solvent and using Cyclic Voltammetry (CV) (Figures S16-S17) and Osteryoung Square Wave Voltammetry (OSWV) (Table 1, Figures S18-S19). On the anodic side both compounds showed a first reversible one-electron oxidation wave at $0.44 \mathrm{~V}$ for $1 \mathrm{a}$ and $0.15 \mathrm{~V}$ for $\mathbf{1 b}$ ( $v s . \mathrm{Fc} / \mathrm{Fc}^{+}$in all cases), which is attributed to the oxidation of the $\mathrm{Zn}$-porphyrin moiety. The first reduction potential of $\mathbf{1 a - b}$ was observed at $-1.40 \mathrm{~V}$ and $-1.45 \mathrm{~V}$, respectively.

These data were transformed into plots of frontier molecular orbital energy levels $v s$. vacuum (see Figure 2). From the first oxidation potential values, the approximate $E_{\text {HOMO values }}$ were determined to be $-5.54 \mathrm{eV}$ and $-5.25 \mathrm{eV}$ for $\mathbf{1 a}$ and $\mathbf{1 b}$, respectively. The lower value of the HOMO energy level in 1a should be beneficial for achieving a higher $V_{\mathrm{oc}}$ of the resultant BHJ OSC (see below). The approximated LUMO values are $-3.70 \mathrm{eV}$ for $1 \mathrm{a}$ and $-3.65 \mathrm{eV}$ for $1 \mathrm{~b}$.

The low LUMO levels contribute to low band gap values $(1.84 \mathrm{eV}$ for $\mathbf{1 a}$ and $1.60 \mathrm{eV}$ for 1b) and the trend is in good agreement with that observed for the optical bandgap. However, the higher bandgap estimated from the CV measurement may be attributed to the electron transfer during the oxidation and reduction processes and energy is needed to overcome the energy barrier formed at electrode/solution interface [18].

\section{Theoretical calculations}

Theoretical calculations were carried out using Gaussian 09W (DFT, B3LYP/6-31G*) in order to gain an insight into the effect that the length of the conjugated bridge has on the electronic properties of $\mathbf{1 a - b}$. First, the optimized structures of $\mathbf{1 a}$ and $\mathbf{1 b}$ were obtained. In both cases, the porphyrin macrocycle is almost coplanar with the conjugated oligothienylenevinylene, which favors the packing by $\pi-\pi$ stacking (Figure S20). The theoretical HOMO and LUMO energy levels and wavefunctions of the frontier molecular orbitals of compounds 1a and 1b were calculated (Figure 3). The electron densities of the HOMO of both compounds are predominantly localized on the porphyrin macrocycle and the 
thienylenevinylene bridge. In contrast, the electron densities of the LUMO are distributed over the whole molecule, meaning that the overlap between the HOMO and LUMO facilitates the HOMO to LUMO electronic transitions.

\section{Photovoltaic properties}

The photovoltaic properties of $\mathbf{1 a}$ and $\mathbf{1 b}$ as donors along with $\mathrm{PC}_{71} \mathrm{BM}$ as an acceptor were investigated using the device structure ITO/PEDOT:PSS/1a or $\mathbf{1 b}: \mathrm{PC}_{71} \mathrm{BM} / \mathrm{Al}$. In $\mathrm{BHJ}$ organic solar cells, the relative amount of the donor to acceptor materials employed in the active layer plays an important role for observed PCE, since there should be a balance between the absorbance and charge-transporting network of the active layer. Therefore, we initially varied the donor to acceptor weight ratio and used chlorobenzene as solvent. It was found that the optimized weight ratio is 1:2 for both 1a and 1b. The current-voltage $(J-V)$ characteristics of the optimized devices are shown Figure 5a and the corresponding photovoltaic parameters are summarized in Table 2.

The device based on 1a: $\mathrm{PC}_{71} \mathrm{BM}$ showed an overall $\mathrm{PCE}$ of $2.30 \%$ with $\mathrm{J}_{\mathrm{sc}}=7.82$ $\mathrm{mA} / \mathrm{cm}^{2}, \mathrm{~V}_{\mathrm{oc}}=0.98 \mathrm{~V}$ and $\mathrm{FF}=0.30$. The organic solar cell based on $\mathbf{1 b}: \mathrm{PC}_{71} \mathrm{BM}$ showed a PCE of $2.80 \%$ with $\mathrm{J}_{\mathrm{sc}}=9.04 \mathrm{~mA} / \mathrm{cm}^{2}, \mathrm{~V}_{\mathrm{oc}}=0.86 \mathrm{~V}$ and $\mathrm{FF}=0.36$. The higher $\mathrm{V}_{\mathrm{oc}}$ for the device based on 1a:PC ${ }_{71} \mathrm{BM}$ is consistent with the deeper HOMO energy level of $1 \mathbf{a}(-5.54$ $\mathrm{eV}$ ) when compared to $\mathbf{1 b}(-5.25 \mathrm{eV})$, since the $\mathrm{V}_{\text {oc }}$ of a $\mathrm{BHJ}$ organic solar is directly related to the difference between the HOMO of the donor and the LUMO of the acceptor. However, the value of $\mathbf{J}_{\mathrm{sc}}$ is higher for $\mathbf{1 b}: \mathrm{PC}_{71} \mathrm{BM}$ when compared to $\mathbf{1 a}: \mathrm{PC}_{71} \mathrm{BM}$. Since $\mathrm{J}_{\mathrm{sc}}$ is directly related to the light harvesting ability of the active layer and the exciton dissociation efficiency of a D/A interface in the BHJ active layer, the low bandgap of $\mathbf{1 b}$ might lead to higher light harvesting ability in comparison to 1a. Moreover, the LUMO offset for $\mathbf{1 b}: \mathrm{PC}_{71} \mathrm{BM}(0.35 \mathrm{eV})$ is higher than that for $1 \mathrm{a}: \mathrm{PC}_{71} \mathrm{BM}(0.30 \mathrm{eV})$ and this may lead to more efficient exciton dissociation in the former. These two combined effects lead to a higher $\mathrm{J}_{\mathrm{sc}}$ for the $\mathbf{1 b}: \mathrm{PC}_{71} \mathrm{BM}$ based organic solar cell when compared to the 1a:PC $\mathrm{PC}_{71} \mathrm{BM}$ counterpart (Figure $4 \mathrm{a}$ ).

In order to understand why the $\mathbf{1 b}: \mathrm{PC}_{71} \mathrm{BM}$ based device displayed higher $\mathrm{J}_{\mathrm{sc}}$ and $\mathrm{PCE}$ values, the incident photon to current conversion efficiency (IPCE) of porphyrin/ $\mathrm{PC}_{71} \mathrm{BM}$ based devices at the optimal conditions were measured. The results are represented in Figure 4b. As shown in Figure 4b, both devices showed wide spectra and these closely resemble the absorption spectra of the corresponding active layers. The IPCE values are higher for the device based on $1 \mathbf{b} / \mathrm{PC}_{71} \mathrm{BM}$ when compared to the $1 \mathrm{a} / \mathrm{PC}{ }_{71} \mathrm{BM}$ device. The integrated values of $\mathbf{J}_{\mathrm{sc}}$ estimated from the IPCE spectra of $\mathbf{1 a} / \mathrm{PC}_{71} \mathrm{BM}$ and $\mathbf{1 b} / \mathrm{PC}_{71} \mathrm{BM}$ are around $7.72 \mathrm{~mA} / \mathrm{cm}^{2}$ 
and $8.96 \mathrm{~mA} / \mathrm{cm}^{2}$, respectively, and these values are consistent with those obtained from the J$\mathrm{V}$ characteristics of the devices under illumination.

In general, the energy loss $\left(E_{\text {loss }}\right)$, defined as $E_{\text {loss }}=E_{g}-q_{o c}$, is one of the most important parameters to evaluate in solar cells and the threshold value is around $0.6 \mathrm{eV} \mathrm{[19]} \mathrm{for} \mathrm{efficient}$ charge transport. The values of $\mathrm{E}_{\text {loss }}$ for $1 \mathrm{a}: \mathrm{PC}_{71} \mathrm{BM}$ and $\mathbf{1 b}: \mathrm{PC}_{71} \mathrm{BM}$ are $0.58 \mathrm{eV}$ and $0.62 \mathrm{eV}$, respectively. The $\mathrm{E}_{\text {loss }}$ for the device based on $1 \mathrm{a}$ is around $0.56 \mathrm{eV}$, which is lower than the threshold value and results in the low $\mathbf{J}_{\mathrm{sc}}$ value. On the other hand, the device based on $\mathbf{1 b}$ had an $E_{\text {loss }}$ that was slightly higher than the threshold, which resulted in a higher $\mathrm{J}_{\mathrm{sc}}$ as compared to 1a. Moreover, an energy loss below $0.6 \mathrm{eV}$ for $1 \mathrm{a}: \mathrm{PC}_{71} \mathrm{BM}$ was observed and this contributes to the high $\mathrm{V}_{\mathrm{oc}}[18 \mathrm{a}]$.

In order to obtain information about the difference in the $\mathrm{J}_{\mathrm{sc}}$ values of these devices, we measured the hole mobility in the active layer using the hole-only devices. The mobility was estimated from the current-voltage characteristics in the dark (Figure 5) and the curves were fitted with the space charge limited current (SCLC) model to give values of $1.07 \times 10^{-5}$ and $1.23 \times 10^{-5} \mathrm{~cm}^{2} / \mathrm{Vs}$ for $\mathbf{1 a}$ and $\mathbf{1 b}$, respectively. There is a slight difference in the hole mobility which cannot explain by itself the measured PCE differences. Therefore, the difference in the $\mathbf{J}_{\mathrm{sc}}$ values may be due to the difference in energy loss and the LUMO offset, as described earlier.

The $V_{\mathrm{oc}}$ of these solar cells is remarkable but the $\mathrm{J}_{\mathrm{sc}}$ and FF values are very low. The $\mathrm{J}_{\mathrm{sc}}$ and FF values are directly related to the exciton dissociation efficiency and charge transport in the device and they are controlled by the nanoscale morphology of the active layer. As reported in the literature, thermal annealing, solvent additives, solvent vapor additives and two-step annealing (combination of thermal and solvent vapor annealing) are adopted to improve the overall PCE of organic BHJ solar cells. For porphyrin-based organic solar cells, pyridine has been used most commonly as a solvent additive to improve the morphology of active layers that consist of porphyrin and $\mathrm{PC}_{71} \mathrm{BM}$ - a phenomenon that we have observed previously [20]. In order to improve the PCE of our devices, pyridine (different volume percentage concentration in host chlorobenzene) was employed as solvent and it was found that 3v \% gives the best photovoltaic response. The current-voltage characteristics of the device based on the solvent-additive active layer are shown in Figure 5a. The device based on $\mathbf{1 a}$ and $\mathbf{1 b}$ showed a PCE of $5.14 \%\left(\mathrm{Jsc}=10.67 \mathrm{~mA} / \mathrm{cm}^{2}, \mathrm{Voc}=0.93 \mathrm{~V}\right.$ and $\left.\mathrm{FF}=0.54\right)$ and $6.06 \%\left(\mathrm{~J}_{\mathrm{sc}}=\right.$ $12.97 \mathrm{~mA} / \mathrm{cm}^{2}, \mathrm{~V}_{\mathrm{oc}}=0.82 \mathrm{~V}$ and $\left.\mathrm{FF}=0.57\right)$, respectively. The improvement in the $\mathrm{J}_{\mathrm{sc}}$ and $\mathrm{FF}$ with a solvent additive indicates that the pyridine plays an important role in optimizing the nanoscale morphology of the active layer. It has been reported in the literature that pyridine 
forms a 1:1 complex with metallo-porphyrins [21] exhibit weak supermolecular interactions with fullerenes. We assume that pyridine interact with $\mathrm{PC}_{71} \mathrm{BM}$ [22] and can promote the mixing of porphyrin with $\mathrm{PC}_{71} \mathrm{BM}$. These supramolecular interactions avoid the selfaggregation of both porphyrins and $\mathrm{PC}_{71} \mathrm{BM}$ during film formation, even for the lower boiling point of pyridine compared to CB. The IPCE spectra of the devices (Figure 4b) showed that the IPCE values throughout the wavelength measurement range are higher for the devices based on a solvent additive when compared to those without an additive. The values estimated from the integration of IPCE spectra are $10.58 \mathrm{~mA} / \mathrm{cm}^{2}$ and $12.87 \mathrm{~mA} / \mathrm{cm}^{2}$ for $\mathbf{1 a}$ and $\mathbf{1 b}$, respectively, and these are in good agreement with the values obtained from $\mathrm{J}-\mathrm{V}$ characteristics.

The hole mobility of pyridine/CB cast films was estimated from the J-V characteristics of hole-only devices in the dark and fitting of these characteristics with the SCLC model (Figure 5). The values for hole mobility were found to be $1.12 \times 10^{-4}$ and $2.34 \times 10^{-4} \mathrm{~cm}^{2} / \mathrm{Vs}$ for 1a: $\mathrm{PC}_{71} \mathrm{BM}$ and $\mathbf{1 b}: \mathrm{PC}_{71} \mathrm{BM}$ based devices, respectively. The increase in hole mobility indicates the more balanced charge transport in the devices based on pyridine/CB when compared to $\mathrm{CB}$ cast devices, thus leading to improvements in $\mathrm{J}_{\mathrm{sc}}$ and $\mathrm{FF}$ and resulting in an enhancement in the PCE of the organic solar cells.

It was found that both $\mathrm{FF}$ and $\mathrm{J}_{\mathrm{sc}}$ of the devices were significantly improved when the active layers were processed with pyridine/CB solvent. To explore the effect of the pyridine solvent additive on the photogeneration of charge carriers and their extraction by the electrodes, the photocurrent density $\left(\mathrm{J}_{\mathrm{ph}}\right)$ was plotted as a function of effective voltage ( $\left.\mathrm{V}_{\text {eff }}\right)$ for the devices (see Figure 6). $\mathrm{J}_{\mathrm{ph}}$ is defined as $\mathrm{J}_{\mathrm{ph}}=\mathrm{J}_{\mathrm{L}}-\mathrm{J}_{\mathrm{D}}$, where $\mathrm{J}_{\mathrm{L}}$ and $\mathrm{J}_{\mathrm{D}}$ are the current densities under illumination and in the dark, respectively. $V_{\text {eff }}$ is defined as $V_{\text {eff }}=V_{o}-V_{\text {appl }}$, where $V_{o}$ is the voltage at which $J_{p h}$ is zero and $V_{\text {app }}$ is the external applied voltage. $V_{\text {eff }}$ is related to the minimum driving force for charge extraction and photocurrent is not generated when $V_{\text {eff }}$ is below zero and is close to the built in potential [23].

For an ideal device, $\mathrm{J}_{\mathrm{ph}}$ increases in a linear manner with $\mathrm{V}_{\text {eff }}$ in the low $\mathrm{V}_{\text {eff }}$ region, which indicates that diffusion plays an important role in photocurrent generation, and at higher $\mathrm{V}_{\text {eff }}$ the drift contribution is dominant and the photocurrent tends to be saturated [24]. The saturation photocurrent density $\left(\mathrm{J}_{\mathrm{ph}, \mathrm{sat}}\right)$ is expressed as: $\mathrm{J}_{\mathrm{ph}, \mathrm{sat}}=\mathrm{qLG}_{\mathrm{max}}$, where $\mathrm{q}$ is the electronic charge, $\mathrm{L}$ is the thickness and $\mathrm{G}_{\max }$ is the number of absorbed photons. The charge collection

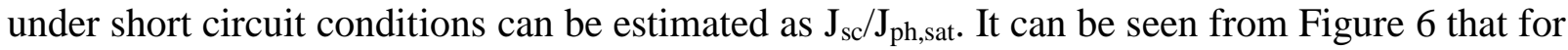
the devices prepared without pyridine as an additive, $\mathrm{J}_{\mathrm{ph}}$ increases in a linear manner with $\mathrm{V}_{\text {eff }}$ up to a comparatively high reverse bias and this does not completely reach saturation. This finding indicates that in these devices there are a lot of photogenerated excitons that can be 
dissociated into free charge carriers and these are not swept out by the electrodes [25]. However, for the devices processed with pyridine/CB solvent, the slope of the linear region is steeper and then becomes saturated. This phenomenon indicates that the bimolecular recombination decreased and charge collection ability increased.

In order to obtain information about the change in the nanoscale morphology of the active layer with the pyridine solvent additive, AFM images (both height and phase) of the active layers were recorded (see Figure 7) for $\mathbf{1 b}: \mathrm{PC}_{71} \mathrm{BM}$. The root mean square (rms) value of surface roughness decreased from $1.78 \mathrm{~nm}$ to $1.12 \mathrm{~nm}$ after addition of the pyridine. This change may occur because the pyridine could be good solvent for $\mathrm{PC}_{71} \mathrm{BM}$ in the host solvent and thus lead to better dispersion and separation between $\mathbf{1 b}$ and $\mathrm{PC}_{71} \mathrm{BM}$. A similar effect was observed for the 1a: $\mathrm{PC}_{71} \mathrm{BM}$ active layer.

A more homogeneous morphology with a domain size in the range of the exciton diffusion length of the BHJ active layer is favorable for exciton dissociation and interpenetrating pathways for charge transport, thus resulting in increased FF and PCE values for the devices.

In order to improve the PCE of our devices on the optimized active layer, we employed a solution-processable bis(trifluoromethane)sulfonimide lithium salt (Li-TFSI) as the interlayer between the optimized active layer and the Al cathode, since the extraction of charge carrier can be improved by using interlayers [25]. The interlayers can enhance both the physical and electronic contact between the active layer and the electrodes. Li-TFSI has been used extensively as an additive in solid-state dye-sensitized solar cells to promote doping of the solid-state electrolyte [26] and it has recently been used for polymeric solar cells [28]. The LiTFSI was deposited from methanol solution. Since, we have found that the effect of Li-TFSI as interlayer on the photovoltaic response of the both the devices based on either 1a:PC71BM and $\mathbf{1 b}: \mathrm{PC}_{71} \mathrm{BM}$ is same, we are only discussing here only for the OSCs based on the pryridine/CB processed $\mathbf{1 b}: \mathrm{PC}_{71} \mathrm{BM}$ active layer. The current-voltage characteristics under illumination and the IPCE spectra of the device are shown in Figures $4 \mathrm{a}$ and $4 \mathrm{~b}$, respectively, and the photovoltaic parameters are summarized in Table 2. The device performance was improved significantly on using Li-TFSI as an interlayer between the active layer and the Al electrode. The $\mathrm{V}_{\mathrm{oc}}$ and FF values increased from $0.82 \mathrm{~V}$ to $0.88 \mathrm{~V}$ and 0.57 to 0.65 , respectively, when LiTFSI was used as an interlayer. It was also observed that $\mathbf{J}_{\mathrm{sc}}\left(13.34 \mathrm{~mA} / \mathrm{cm}^{2}\right)$ also improved when compared to that for the Al electrode and the overall PCE improved to $7.63 \%$. The $\mathrm{J}_{\mathrm{sc}}$ value estimated from the integration of the IPCE spectra (Figure $4 \mathrm{~b}$ ) is around $13.39 \mathrm{~mA} / \mathrm{cm}^{2}$, which is in good agreement with the value obtained from the J-V characteristics under 
illumination. The interlayer substantially lowered the series resistance $\left(R_{s}\right)$ and increased the shunt resistance $\left(R_{s h}\right)$. The reduction in $R_{s}$ indicates the effective reduction of contact resistance by the formation of an interface dipole between the PCBM and the Al electrode [29]. It is assumed that this enhancement may be due to a reduction in the vacuum level due to the interfacial dipole induced by the insertion of LiTFSI, as reported for organic solar cells based on polymers [28]. The dipole layer of LiTFSI shifts the vacuum level of the adjacent negative electrode layer upwards, thus leading to better transport and extraction when aligned with LiTFSI and improving the $\mathrm{J}_{\mathrm{sc}}$ and FF values.

In order to obtain further information about the influence that LiTFSI has on the electrical properties of the $1 \mathbf{b}: \mathrm{PC}_{71} \mathrm{BM}$ photoactive layer and/or the interface between each layer, impedance spectroscopy (IS) was carried out (Figure 8).

The IS study showed a reduction in the interfacial resistance for the device with LiTFSI, as evidenced by the decrease in the radius of the Nyquist plot (Figure 8a). In addition, the lifetimes of the charge carrier were estimated from the IS measurement. The high frequency peak in the Bode phase plot (Figure $8 \mathrm{~b}$ ) indicates that charge transfer and the reciprocal of this frequency define the effective charge lifetime [30]. The electron lifetime of the OSC with and without LiTFSI was calculated to be 22.46 and $10.14 \mu$ s for the device with and without LiTFSI, respectively. These values show that the OSC with LiTFSI undergoes less recombination and more efficient charge transport. We investigated the capacitance-voltage $(\mathrm{C}-\mathrm{V})$ characteristics in an effort to understand the influence that the LiTFSI layer between the active layer and the Al electrode has on the internal electric field in the OSC [31] (see Figure 9).

In the OSC the intrinsic p-doped nature of the organic semiconductor leads to the formation of Schottky contact between the electrode and the active layer. The C-V measurements were performed by applying a small AC signal with fixed frequency and sweeping the DC bias from reverse bias to forward bias and it was further investigated by considering a Mott-Schottky plot using $\mathrm{N}=-2(\mathrm{dC} / \mathrm{dV})^{-1} / \mathrm{q} \varepsilon_{0} \varepsilon_{\mathrm{r}} \mathrm{A}^{2}$ [31], where $\mathrm{q}$ is the electronic charge, $\varepsilon_{o}$ is the permittivity of a vacuum, $\varepsilon_{\mathrm{r}}$ is the relative permittivity (dielectric constant) of the active layer (assumed to be 3.5) and $\mathrm{N}$ is the charge carrier concentration. From the intercept on the voltage axis, we estimated the values of $V_{b i}$ to be around $0.80 \mathrm{~V}$ and $0.88 \mathrm{~V}$ for the devices without and with the LiTFSI layer, respectively. The increase in $\mathrm{V}_{\mathrm{bi}}$ matches the improvement in $\mathrm{V}_{\mathrm{oc}}$ and this indicates that the insertion of the LiTFSI layer strengthens the built in field, thus leading to an improvement in $\mathrm{J}_{\mathrm{sc}}$ and $\mathrm{FF}$ as a result of more efficient charge extraction and the reduction of charge recombination. The value of $\mathrm{N}$ is around 
$5.45 \times 10^{16} \mathrm{~cm}^{-3}$ and $8.82 \times 10^{16} \mathrm{~cm}^{-3}$ without and with Li-TFSI treatment, respectively. The increase in $\mathrm{N}$ after the insertion of Li-TFSI may lead to an increase in surface charge density, which in turn would increase the surface potential [32].

Although, the FF has been significantly improved after the Li-TFSI treatment but is still low as compared to other devices reported in literature, may be due the unbalanced charge transport and recombination losses during the extraction of charge carriers.

\section{Conclusions}

In summary, we have synthesized two new new conjugated acceptor- $\pi$-donor- $\pi$-acceptor $(\mathrm{A}-\pi-\mathrm{D}-\pi-\mathrm{A})$ small molecules with a porphyrin core linked by ethynylene bridges to thienylenevinylenethiophene and capped by 3-ethylrhodanine (1a) or dicyanovinylene (1b) groups as acceptor units. The optical and electrochemical properties of these materials were investigated and they were used as donors along with $\mathrm{PC}_{71} \mathrm{BM}$ as an electron acceptor for the fabrication of conventional solution-processed bulk heterojunction organic solar cells. The weight ratio between donor (1a or $\mathbf{1 b})$ and $\mathrm{PC}_{71} \mathrm{BM}$ and the concentration of pyridine solvent additive were optimized. The resulting devices with 1a and 1b showed PCE values of 5.14\% and $6.06 \%$, respectively. The use of LiTFSI as an interlayer between pyridine/CB processed $\mathbf{1 b}: \mathrm{PC}_{71} \mathrm{BM}$ led to a PCE of $7.63 \%$ for $\mathbf{1 b}: \mathrm{PC}_{71} \mathrm{BM}$. The improvement in PCE is attributed to the simultaneous increase in $J_{\mathrm{sc}}, V_{\mathrm{oc}}$ and FF due to the increase in the built in potential induced by the interlayer.

\section{Acknowledgments}

We are grateful for financial support from the MINECO, Spain (CTQ2013-48252-P) and Junta de Comunidades de Castilla-La Mancha, Spain (PEII-2014-014-P). SA thanks the Fundación Carolina for a grant. EP would like to thank projects CTQ-2013-47183-R, the Severo Ochoa Excellence Accreditation 2014.20188SEV-2103-0319) and the AGAUR 2014 SGR-763. GDS would like to thank Director, The LNMIIT for financial support.

\section{Supporting Information}

Supporting Information is available from the Wiley Online Library or from the author.

\section{References}

1. (a) G. Li, R. Zhu and Y. Yang, Nature Photon., 2012, 6, 153; (b) L. Lu, T. Zheng, Q. Wu, A. M. Schneider, D. Zhao, L. Yu, Chem. Rev., 2015, 115, 12666.

2. (a) Z. He, B. Xiao, F. Liu, H. Wu, Y. Yang, S. Xiao, C. Wang, T. P. Russell, Y. Cao, Nature Photon., 2015, 9, 174, (b) V. Vohra, K. Kawashima, T. Kakara, T. Koganezawa, I. 
Osaka, K. Takimiya, H. Murata, Nature Photon., 2015, 9, 403; (c) C. Liu, C. Yi, K. Wang, Y. Yang, R. S. Bhatta, M. Tsige, S. Xiao, X. Gong, ACS Appl. Mater. Interfaces, 2015, 7, 4928; (d) J. Zhao, Y. Li, G. Yang, K. Jiang, H. Lin, H. Ade, W. Ma, H. Yan, Nat. Energy, 2016, 1, 16070; (e) Y. Liu, J. Zhao, Z. Li, C. Mu, W. Ma, H. Hu, K. Jiang, H. Lin, H. Ade, H. Yan, Nat. Commun., 2014, 5, 5293; (f) H. Hu, K. Jiang, G. Yang, J. Liu, Z. Li, H. Lin, Y. Liu, J. Zhao, J. Zhang, F. Huang, Y. Qu, H. Yan, J. Am. Chem. Soc., 2015, 137, 14159; (g) J. Chen, C. Cui, Y. Li, L. Zhou, Q. Ou, C. Li, Y. Li, J. Tang, Adv. Mater., 2015, 27, 1035; (h) J. Kim, Z. Hong, G. Li, T. Song, J. Chey, Y. Lee, J. You, C. Chen, D. K. Sadana, Y. Yang, Nat. Commun., 2015, 6, 6391; (i) X. Ouyang, R. Peng, L. Ai, X. Zhang, Z. Ge, Nature Photon., 2015, 9, 520; (j) J. Zhang, Y. Zhang, J. Fang, K. Lu, Z. Wang, W. Ma, Z. Wei, J. Am. Chem. Soc., 2015, 137, 8176.

3. J. Wolf, M. Babics, K. Wang, Q. Saleem, R. Liang, M. R. Hansen, P. M. Beaujuge, Chem. Mater., 2016, 28, 2058; (b) Y. Lin and X. Zhan, Acc. Chem. Res., 2016, 49, 175; (c) X. Liu, H. Chen, S. Tan, Renew. Sust. Energ. Rev., 2015, 52, 1527; (d) W. Ni, X. Wan, M. Li, Y. Wang, Y. Chen, Chem. Commun., 2015, 51, 4936; (e) A. Mishra, P. Bäuerle, Angew. Chem. Int. Ed., 2012, 51, 2020; (f) Y. Lin, Y. Li, X. Zhan, Chem. Soc. Rev., 2012, 41, 4245 .

4. B. Kan, Q. Zhang, M. Li, X. Wan, W. Ni, G. Long, Y. Wang, X. Yang, H. Feng, Y. Chen, J. Am. Chem. Soc., 2014, 136, 15529.

5. Heliatek GmbH, Heliatek sets new Organic Photovoltaic world record efficiency of 13.2\%, Press release (Feb. 08, 2016), http://www.heliatek.com/en/press/press-releases /details /heliatek-sets-new-organic-photovoltaicworld-record-efficiency-of-13-2.

6. T. S. Balaban, Acc. Chem. Res., 2005, 38, 612; (b) D. Astruc, E. Boisselier, C. Ornelas, Chem. Rev., 2010, 110, 1857; (c) W.-K. Wong, X. Zhu, W.-Y. Wong, Coord. Chem. Rev., 2007, 251, 2386.

7. G. Calogero, G. D. Marco, S. Caramori, S. Cazzanti, R. Argazzi, C. A. Bignozzi, Energy Environ. Sci., 2009, 2, 1162.

8. S. Fukuzumi, Y. Endo, H. Imahori, J. Am. Chem. Soc., 2002, 124, 10974.

9. (a) C. W. Tang, A. C. Albrecht, Nature, 1975, 254, 507; (b) A. Goetzberger, C. Hebling and H. W. Schock, Mater. Sci. Eng., 2003, 40, 1.

10. (a) C. W. Lee, H. P. Lu, C. M. Lan, Y. L. Huang, Y. R. Liang, W. N. Yen, Y. C. Liu, Y. S. Lin, E. W. G. Diau, C. Y. Yeh, Chem. Eur. J., 2009, 15, 1403; (b) C. L. Mai, W. K. Huang, H. P. Lu, C. W. Lee, C. L. Chiu, Y. R. Liang, E. W. G. Diau, C. Y. Yeh, Chem. Commun., 2010, 46, 809. 
11. (a) S. Mathew, A. Yella, P. Gao, R. Humphry-Baker, B. F. E. Curchod, N. Ashari-Astani, I. Tavernelli, U. Rothlisberger, M. K. Nazeeruddin, M. Grätzel, Nat. Chem., 2014, 6, 242; (b) M. Urbani, M. Grätzel, M. K. Nazeeruddin, T. Torres, Chem. Rev., 2014, 114, 12330.

12. (a) J. Hatano, N. Obata, S. Yamaguchi, T. Yasuda, Y. Matsuo, J. Mater. Chem., 2012, 22, 19258; (b) Y. Huang, L. Li, X. Peng, J. Peng, Y. Cao, J. Mater. Chem., 2012, 22, 21841; (c) L. Li, Y. Huang, J. Peng, Y. Cao, X. Peng, J. Mater. Chem. A, 2013, 1, 2144; (d) G. D. Sharma, D. Daphnomili, S. Biswas, A. G. Coutsolelos, Org. Electron., 2013, 14, 1811; (e) H. Qin, L. Li, F. Guo, S. Su, J. Peng, Y. Cao, X. Peng, Energy Environ. Sci., 2014, 7, 1397; (f) C. V. Kumar, L. Cabau, E. N. Koukaras, G. D. Sharma, E. Palomares, Nanoscale, 2015, 7, 179; (g) G. D. Sharma, G. E. Zervaki, P. A. Angaridis, T. N. Kitsopoulos, A. G. Coutsolelos, J. Phys. Chem. C, 2014, 118, 5968; (h) S. Chen, L. Xiao, X. Zhu, X. Peng, W. K. Wong, W. Y. Wong, Chem. Commun., 2015, 51, 14439; (i) L. Li, L. Xiao, H. Qin, K. Gao, J. Peng, Y. Cao, F. Liu, T. P. Russell, X. Peng, ACS Appl. Mater. Interfaces, 2015, 7, 21495; (j) C. V. Kumar, L. Cabau, E. N. Koukaras, A. Sharma, G. D. Sharma, E. Palomares, J. Mater. Chem. A, 2015, 3, 16287; (k) K. Gao, L. Li, T. Lai, L. Xiao, Y. Huang, F. Huang, J. Peng, Y. Cao, F. Liu, T. P. Russell, R. A. J. Janssen, X. Peng, J. Am. Chem. Soc., 2015, 137, 7282; (1) K. Gao, J. Miao, L. Xiao, W. Deng, Y. Kan, T. Liang, C. Wang, F. Huang, J. Peng, Y. Cao, F. Liu, T. P. Russell, H. Wu, X. Peng, Adv. Mater., 2016, 28, 4727.

13. (a) J. Roncali, Acc. Chem. Res. 2000, 33, 147. (b) S. Rodríguez Gonzalez, M. C. Ruiz Delgado, R. Caballero, P. de La Cruz, F. Langa, J. T. López Navarrete, J. Casado, J. Am. Chem. Soc. 2012, 134, 5675. (c) F. Oswald, D. M. S. Islam, Y. Araki, V. Troiani, R. Caballero, P. de la Cruz, A. Moreno, O. Ito, F. Langa, Chem. Commun., 2007, 4498. (d) F. Oswald, D.-M. S. Islam, M. E. El-Khouly, Y. Araki, R. Caballero, P. de la Cruz, O. Ito, F. Langa, Phys. Chem. Chem. Phys., 2014, 16, 2443.

14. S. J. Lee, K. L. Mulfort, X. Zuo, A. J. Goshe, P. J. Wesson, S. T. Nguyen, J. T. Hupp, D. M. Tiede, J. Am. Chem. Soc., 2008, 130, 836.

15. (a) S. Arrechea, A. Molina-Ontoria, A. Aljarilla, P. de la Cruz, F. Langa, L. Echegoyen, Dyes Pigments, 2015, 121, 109; (c) G. Morán, S. Arrechea, P. de la Cruz, V. Cuesta, S. Biswas, E. J. Palomares, G. D. Sharma, F. Langa, J. Mater. Chem. A, 2016, 4, 11009.

16. R. Fitzner, E. Reinold, A. Mishra, E. Mena-Osteritz, H. Ziehlke, C. Körner, K. Leo, M. Riede, M. Weil, O. Tsaryova, A. Weiß, C. Uhrich, M. Pfeiffer, P. Bäuerle, Adv. Funct. Mater., 2011, 21, 897.

17. M. C. Balaban and T. S. Balaban, J. Porphyr. Phthalocyanines, 2007, 11, 277. 
18. H. J. Son, W. Wang, T. Xiu, Y. Liang, Y. Wu, G. Li, L. Yu, J. Am. Chem. Soc., 2011, 133, 1885.

19. (a) D. Veldman, S. C. J. Meskers, R. A. J. Janssen, Adv. Funct. Mater., 2009, 19, 1939; (b) K. Gao, L. Li, T. Lai, L. Xiao, Y. Huang, F. Huang, J. Peng, Y. Cao, F. Liu, T. P. Russell, R. A. J. Janssen, X. Peng, J. Am. Chem. Soc., 2015, 137, 7282; (c) Y. Hunag, L. Li, X. Peng, Y. Cao, J. Mater. Chem., 2012, 22, 21841.

20. (a) H. Qin, L. Li, F. Guo, S. Su, J. Peng, Y. Cao, X. Peng, Energy Environ. Sci., 2014, 7, 1397; (b) C. V. Kumar, L. Cabau, E. N. Koukaras, G. D. Sharma, E. Palomares, Nanoscale, 2015, 7, 179; (c) G. D. Sharma, S. A. Siddiqui, A. Nikiforou, G E. Zervaki, I. Georgakaki, K. Ladomenou, A. G. Coutsolelos, J. Mater. Chem. C, 2015, 3, 6209.

21. (a) P. N. Taylor, H. L. Anderson, J. Am. Chem. Soc., 1999, 121, 11538; (b) S. Belanger, M. H. Keefe, J. L. Welch, J. T. Hupp, Coord. Chem. Rev., 1999, 192, 29; (c) J. D. Zimmerman, E. K. Yu, V. V. Diev, K. Hanson, M. E. Thompson, S. R. Forrest, Org. Electron., 2011, 12, 869.

22. J.-C. Chen, C.-L. Liu, Y.-S. Sun, S.-H. Tung, W.-C. Chen, Soft Matter, 2012, 8, 526.

23. A. K. K. Kyaw, D. H. Wang, D. Wynands, J. Zhang, T. Q. Nguyen, G. C. Bazan, A. J. Heeger, Nano Lett., 2013, 13, 3796.

24. L. J. A. Koster, V. D. Mihailetchi, R. Ramaker, P. W. M. Blom, Appl. Phys. Lett., 2005, 86,123509 ,

25. V. D. Mihailetchi, L. J. A. Koster, J. C. Hummelen, P. W. M. Blom, Phys. Rev. Lett., 2004, 93, 216601.

26. (a) T.-H. Lai, S.-W. Tsang, J. R. Manders, S. Chen, F. So, Mater. Today, 2013, 16, 424;

(b) E. L. Ratcliff, B. Zacher, N. R. Armstrong, J. Phys. Chem. Lett., 2011, 2, 1337; (c) L.M. Chen, Z. Xu, Z. Hong, Y. Yang, J. Mater. Chem., 2010, 20, 2575; (d) J. H. Park, T.-W. Lee, B.-D. Chin, D. H. Wang, O. O. Park, Macromol. Rapid Commun., 2010, 31, 2095; (e) N. Chakravarthi, K. Gunasekar, W. Cho, D. X. Long, Y.-H. Kim, C. E. Song, J.-C. Lee, A. Facchetti, M. Song, Y.-Y. Noh, S.-H. Jin, Energy Environ. Sci., 2016, DOI: $10.1039 / \mathrm{c} 6 \mathrm{ee} 00292 \mathrm{~g}$.

27. (a) W. H. Nguyen, C. D. Bailie, E. L. Unger, M. D. McGehee, J. Am. Chem. Soc., 2014, 136, 10996; (b) M. Grätzel, U. Bach, D. Lupo, P. Comte, J. E. Moser, F. Weissörtel, J. Salbeck, H. Spreitzer, Nature, 1998, 395, 583.

28. M. Gao, J. Subbiah, P. B. Geraghty, M. Chen, B. Purushothaman, X. Chen, T. Qin, D. Vak, F. H. Scholes, S. E. Watkins, M. Skidmore, G. J. Wilson, A. B. Holmes, D. J. Jones, W. W. H. Wong, Chem. Mater., 2016, 28, 3481. 
29. (a) V. D. Mihailetchi, P. W. M. Blom, J. C. Hummelen, M. T. Rispens, J. Appl. Phys., 2003, 94, 6849; (b) C. J. Brabec, A. Cravino, D. Meissner, N. S. Sariciftci, T. Fromherz, M. T. Rispens, L. Sanchez, J. C. Hummelen, Adv. Funct. Mater., 2001, 11, 374.

30. B. J. Leever, C. A. Bailey, T. J. Marks, M. C. Hersam, M. F. Durstock, Adv. Energy Mater., 2012, 2, 120.

31. P. P. Boix, J. Ajuria, I. Etxebarria, R. Pacios, G. Garcia-Belmonte, J. Bisquert, J. Phys. Chem. Lett., 2011, 2, 407.

32. Q. Wang, Y. Zhou, H. Zheng, J. Shi, C. Z. Li, C. M. Q. Su, L. Wang, C. Luo, D. G. Hu, J. Pei, J. Wang, J. B. Peng, Y. Cao, Org. Electron., 2011, 12, 1858.

Table 1 Absorption, ${ }^{\mathrm{a}}$ emission ${ }^{\mathrm{a}}$ and OSWV data for porphyrins $\mathbf{1 a}$ and $\mathbf{1 b}$

\begin{tabular}{|c|c|c|c|c|c|c|c|c|}
\hline & $\begin{array}{c}\lambda_{\max } \text { sol } \\
(\mathrm{nm})\end{array}$ & $\begin{array}{l}\log \\
(\varepsilon)\end{array}$ & $\begin{array}{l}\lambda_{\mathrm{em}} \\
(\mathrm{nm})\end{array}$ & $\begin{array}{c}E_{o x}^{1} b, c \\
(V)\end{array}$ & $\begin{array}{l}\mathrm{E}_{\text {red }}^{1} \\
(\mathrm{~V})\end{array}$ & $\begin{array}{c}\text { Eномо }^{\mathrm{d}} \\
(\mathrm{eV})\end{array}$ & $\begin{array}{c}\mathrm{E}_{\mathrm{LUMO}}{ }^{\mathrm{e}} \\
(\mathrm{eV})\end{array}$ & $\begin{array}{l}E_{g}{ }^{f} \\
(e V)\end{array}$ \\
\hline \multirow[t]{3}{*}{$1 \mathbf{a}$} & 484 & 5.05 & 741 & 0.44 & -1.40 & -5.54 & -3.70 & 1.84 \\
\hline & 552 & 5.11 & & & & & & \\
\hline & 714 & 5.17 & & & & & & \\
\hline \multirow[t]{3}{*}{$1 b$} & 488 & 4.96 & 754 & 0.15 & -1.45 & -5.25 & -3.65 & 1.60 \\
\hline & 546 & 4.94 & & & & & & \\
\hline & 714 & 5.01 & & & & & & \\
\hline
\end{tabular}

${ }^{a} 10^{-5} \mathrm{M}$ in dichloromethane; ${ }^{b} 10^{-3} \mathrm{M}$ in ODCB-acetonitrile (4:1) versus $\mathrm{Fc} / \mathrm{Fc}^{+}\left(\mathrm{E}_{\mathrm{ox}}=0.04 \mathrm{~V}\right)$ glassy carbon, Pt counter electrode, $20{ }^{\circ} \mathrm{C}, 0.1 \mathrm{M} \mathrm{Bu}_{4} \mathrm{NClO}_{4}$, scan rate $=100 \mathrm{mV} \mathrm{s}{ }^{-1} ;{ }^{c}$ reversible processes; ${ }^{d}$ calculated with respect to ferrocene, $\mathrm{E}_{\mathrm{HO} о \mathrm{O}}:-5.1 \mathrm{eV} ;{ }^{e}$ estimated from $E^{1}{ }_{\text {red }} ;{ }^{\mathrm{f}} \mathrm{Eg}=\mathrm{EHOMO}_{\mathrm{H}}-\mathrm{E}_{\mathrm{LUMO}}$. 
Table 2 Summary of the photovoltaic parameters of OSCs based on $1 \mathrm{a}: \mathrm{PC}_{71} \mathrm{BM}$ and 1b: $\mathrm{PC}_{71} \mathrm{BM}$ active layers measured under $100 \mathrm{~mW} / \mathrm{cm}^{2}$

\begin{tabular}{|l|c|c|c|c|c|c|}
\hline Processing condition & $\begin{array}{c}\mathrm{J}_{\mathrm{sc}} \\
\left(\mathrm{mA} / \mathrm{cm}^{2}\right)\end{array}$ & $\begin{array}{c}\mathrm{V}_{\mathrm{oc}} \\
(\mathrm{V})\end{array}$ & FF & PCE $(\%)$ & $\begin{array}{c}\mathrm{R}_{\mathrm{s}} \\
\left(\Omega \mathrm{cm}^{2}\right)\end{array}$ & $\begin{array}{c}\mathrm{R}_{\mathrm{sh}} \\
\left(\Omega \mathrm{cm}^{2}\right)\end{array}$ \\
\hline $\mathbf{1 a}: \mathrm{PC}_{71} \mathrm{BM}(\mathrm{CB})$ & 7.82 & 0.98 & 0.30 & $2.30(2.23)^{\mathrm{a}}$ & 54 & 254 \\
\hline $\mathbf{1 b}: \mathrm{PC}_{71} \mathrm{BM}(\mathrm{CB})$ & 9.04 & 0.86 & 0.36 & $2.80(2.73)^{\mathrm{a}}$ & 46 & 268 \\
\hline $\mathbf{1 a}: \mathrm{PC}_{71} \mathrm{BM}(\mathrm{pyr} / \mathrm{CB})$ & 10.67 & 0.93 & 0.54 & $5.14(5.08)^{\mathrm{a}}$ & 24 & 389 \\
\hline $\mathbf{1 b}: \mathrm{PC}_{71} \mathrm{BM}(\mathrm{pyr} / \mathrm{CB})$ & 12.97 & 0.82 & 0.57 & $6.06(5.98)^{\mathrm{a}}$ & 18.06 & 423 \\
\hline $\mathbf{1 b}: \mathrm{PC}_{71} \mathrm{BM}(\mathrm{pyr} / \mathrm{CB}) /$ LiTFSI & 13.34 & 0.88 & 0.65 & $7.63(7.58)^{\mathrm{a}}$ & 12.32 & 465 \\
\hline
\end{tabular}

${ }^{a}$ Average of five devices
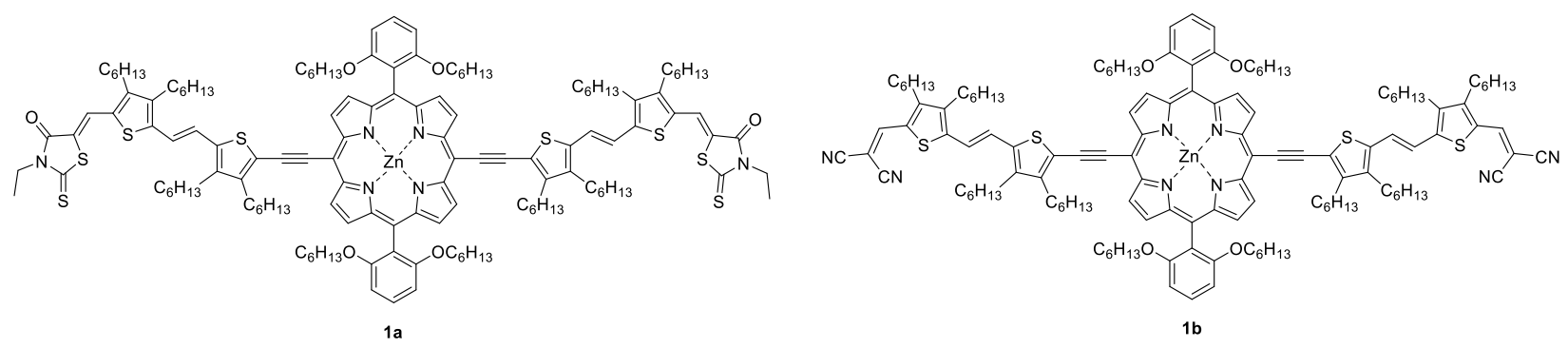

Scheme 1 Structure of $\mathbf{1 a}$ and $\mathbf{1 b}$
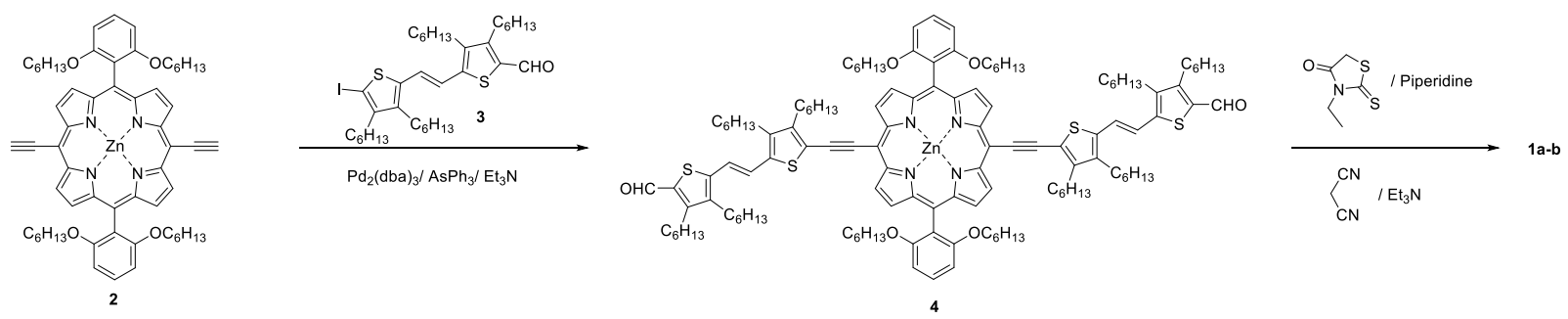

Scheme 2 Synthetic route to $\mathbf{1 a}$ and $\mathbf{1 b}$ 

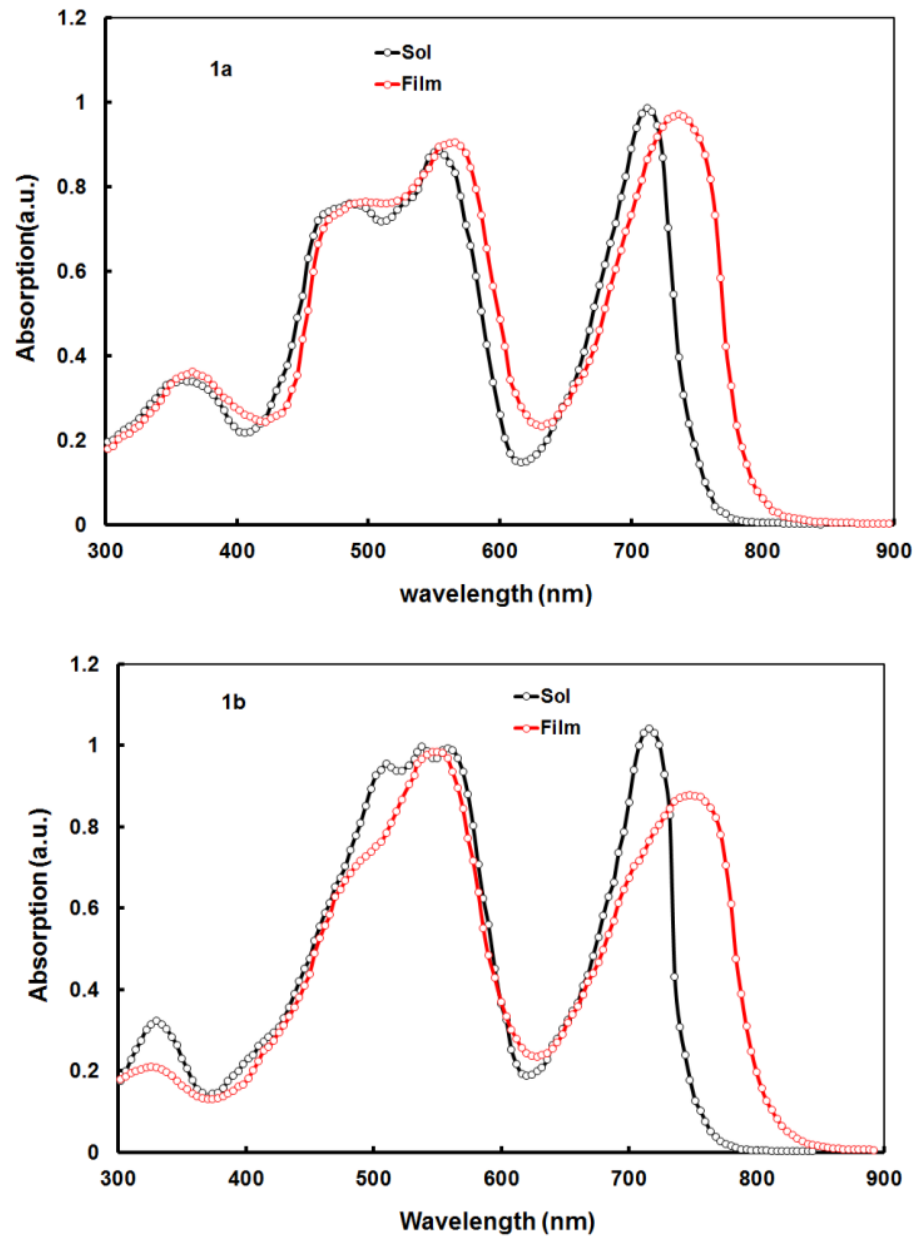

Figure 1 Normalized absorption spectra of $\mathbf{1 a}$ and $\mathbf{1 b}$ in solution (black line) and thin film cast from THF solvent (red line).

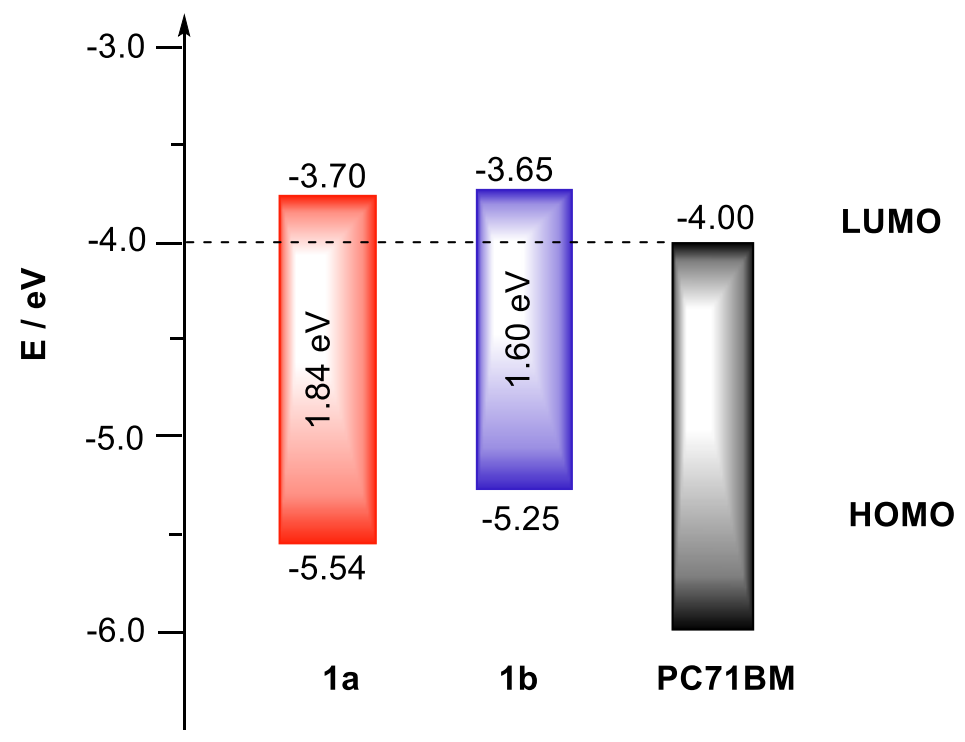

Figure 2 FMO energy levels and band gap (solid area) of molecules $\mathbf{1 a - b}$ and their relative position to the $\mathrm{LUMO}$ of $\mathrm{PC}_{71} \mathrm{BM}$ 

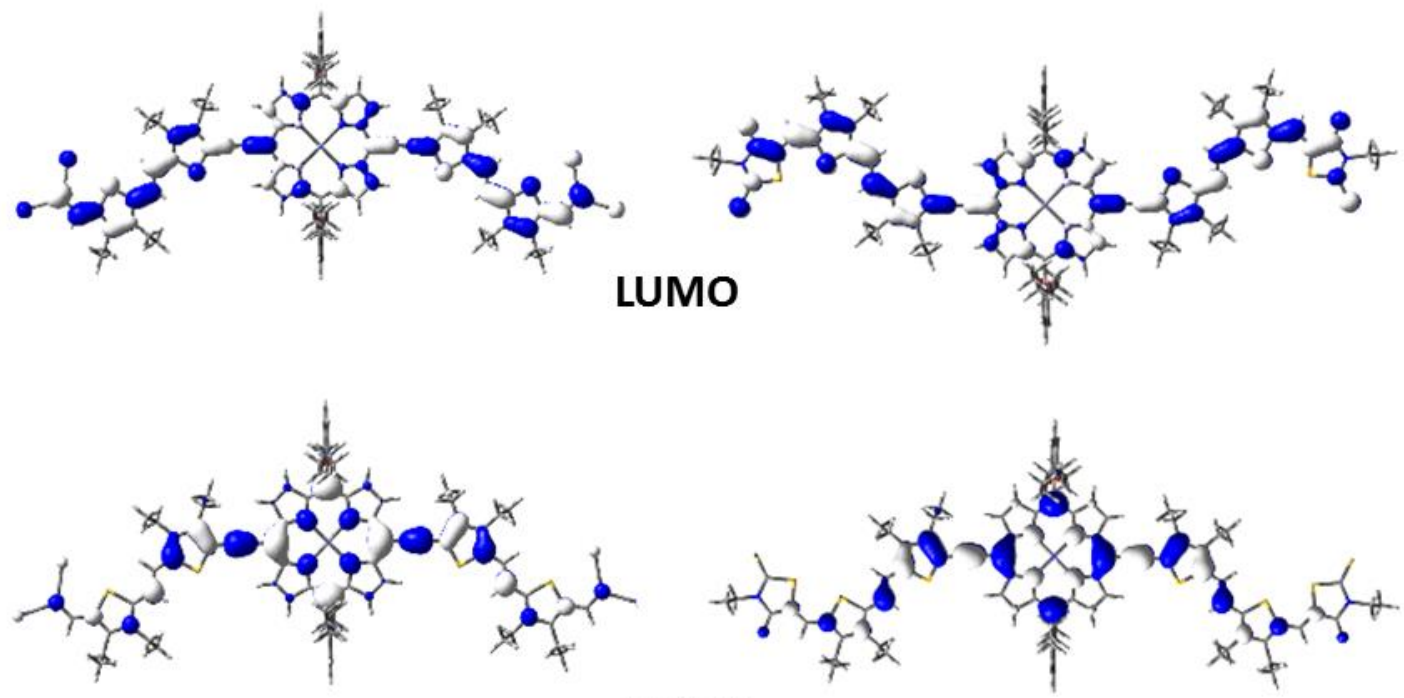

HOMO

$1 a$

$1 \mathrm{~b}$

Figure 3 Electronic density distribution for HOMO and LUMO calculated for $\mathbf{1 a}$ (left) and $\mathbf{1 b}$ (right). For simplicity, hexyl chains are replaced by methyl groups. 

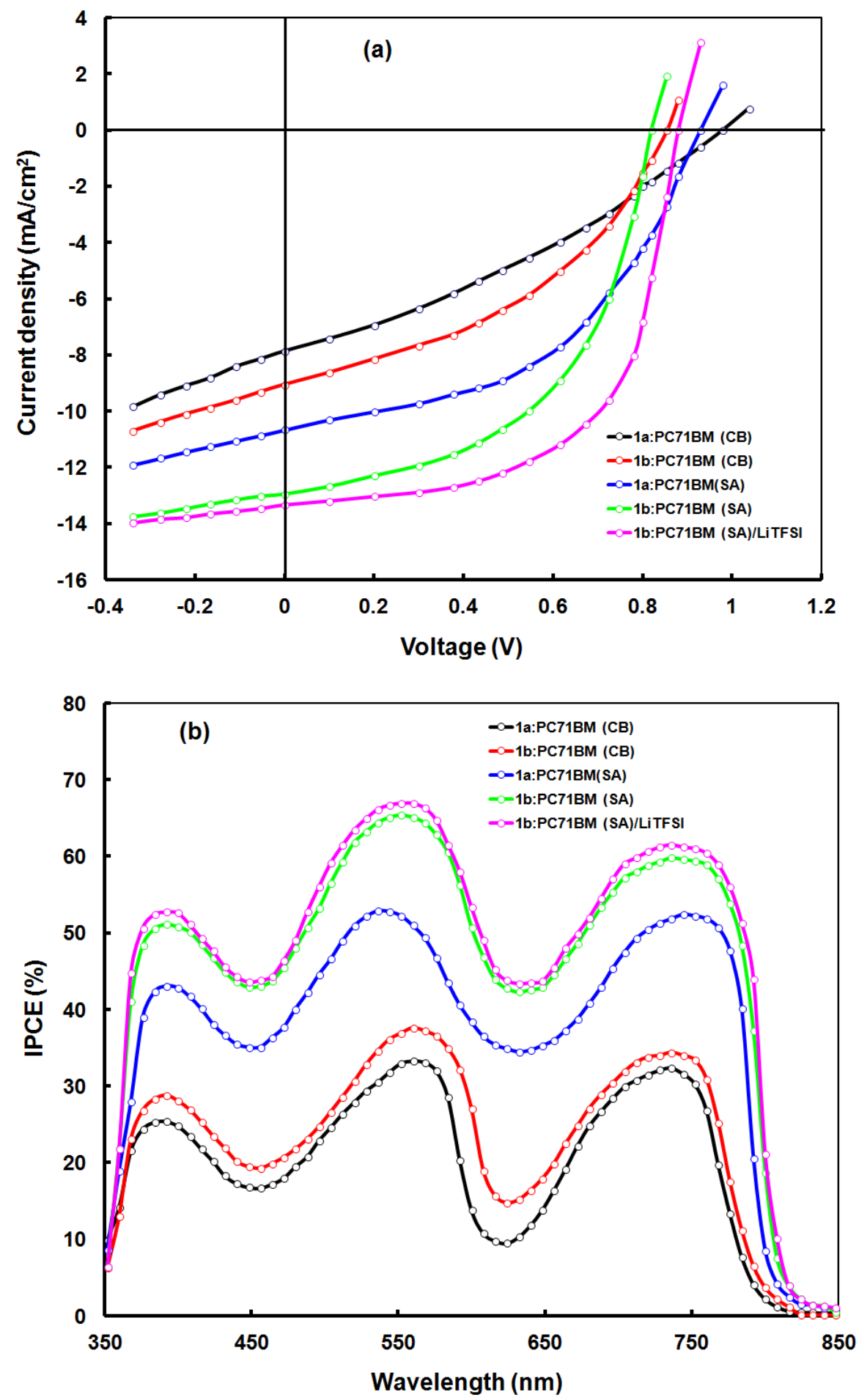

Figure 4 (a) Current-voltage characteristics under illumination and (b) IPCE spectra of the OSCs based on 1a:PC ${ }_{71} \mathrm{BM}$ and $\mathbf{1 b}: \mathrm{PC}_{71} \mathrm{BM}$ optimized active layers 


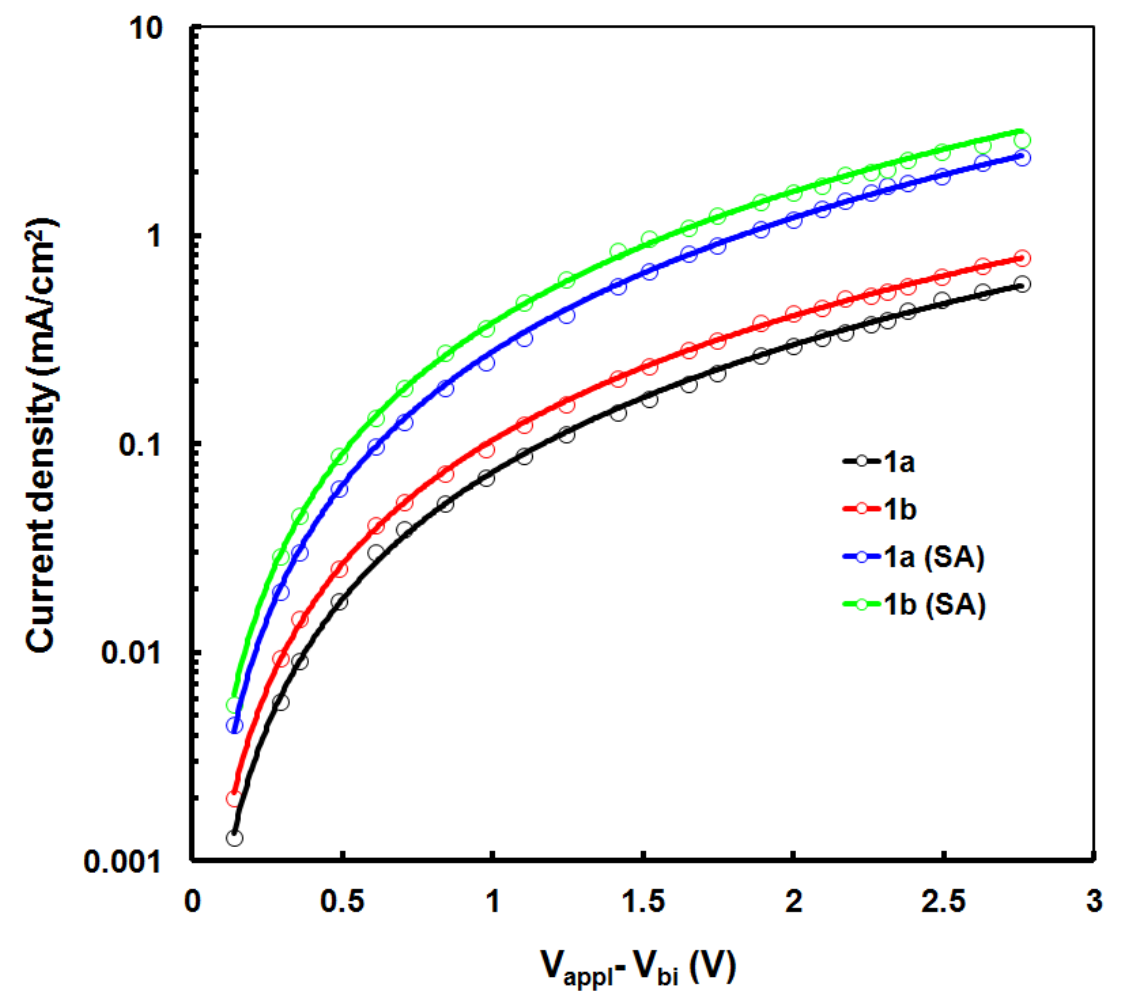

Figure 5 Current-voltage characteristics of hole-only devices based on $1 \mathbf{a}: \mathrm{PC}_{71} \mathrm{BM}$ and $\mathbf{1 b}: \mathrm{PC}_{71} \mathrm{BM}$ active layer with and without pyridine additives

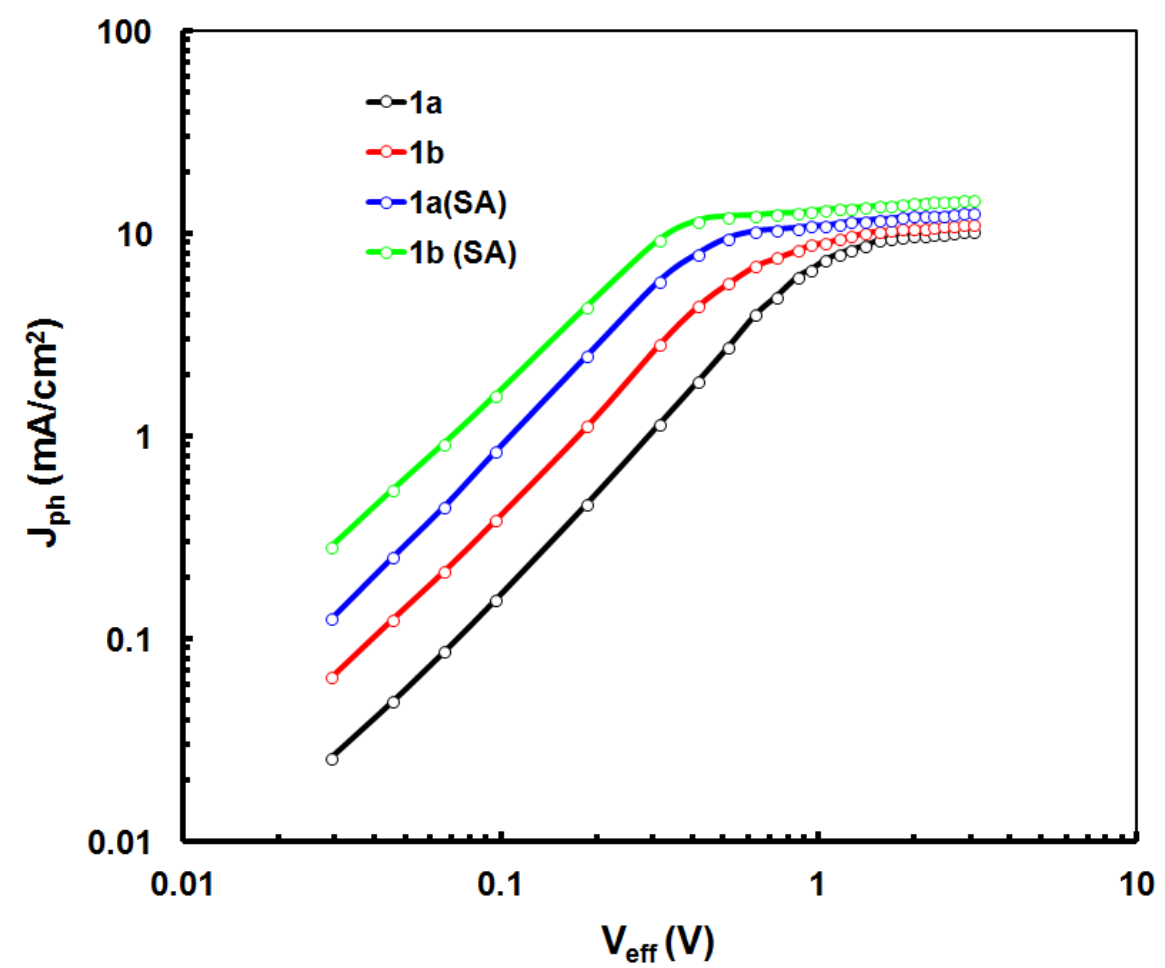

Figure 6 Variation of $J_{\mathrm{ph}}$ with effective voltage ( $\mathrm{V}_{\text {eff }}$ ) for the OSCs based on 1a:PC ${ }_{71} \mathrm{BM}$ and $\mathbf{1 b}: \mathrm{PC}_{71} \mathrm{BM}$ active layer with and without pyridine additives 
(a)

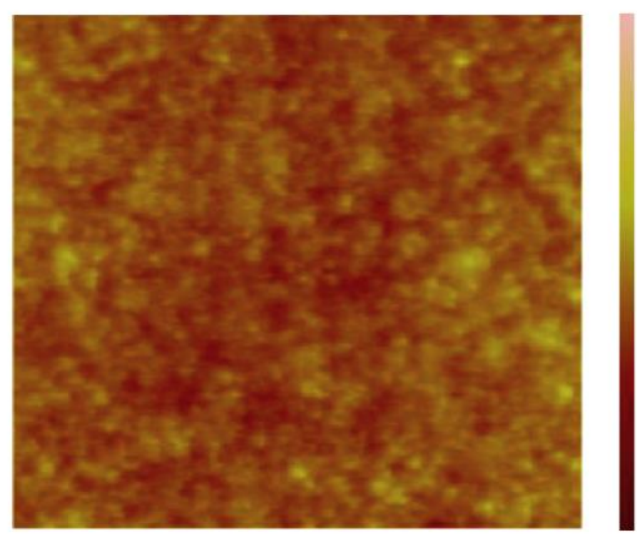

(c)

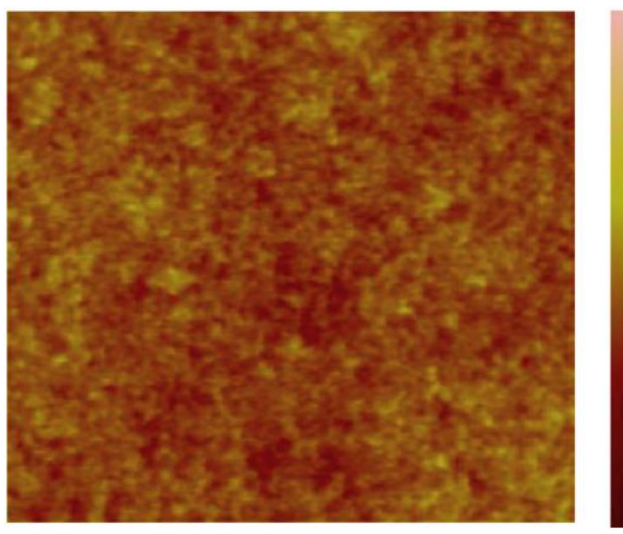

$20 \mathrm{~nm}$

(b)

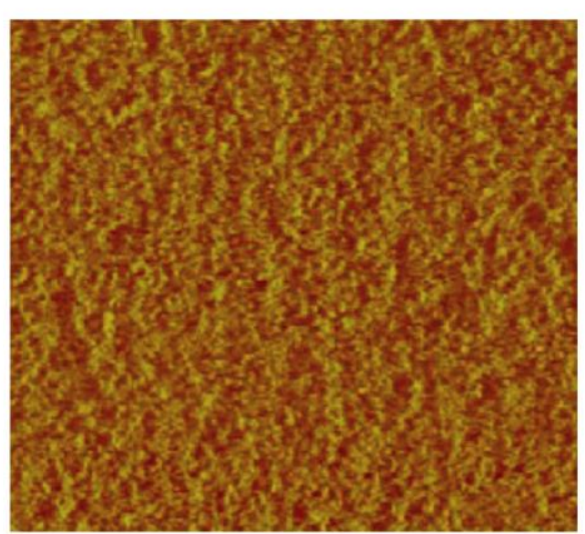

$20 \mathrm{~nm}$

(d)

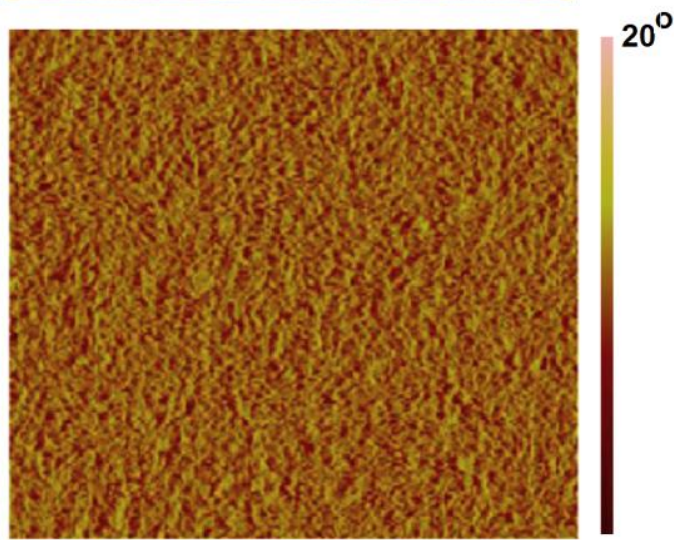

Figure 7 AFM height images (a, $c$ for $C B$ and pyridine/CB processed $1 \mathbf{b}: \mathrm{PC}_{71} \mathrm{BM}$ films, respectively) and phase images $\left(b, d\right.$ for $\mathrm{CB}$ and pyridine/CB processed $1 \mathbf{b}: \mathrm{PC}_{71} \mathrm{BM}$ films, respectively) 

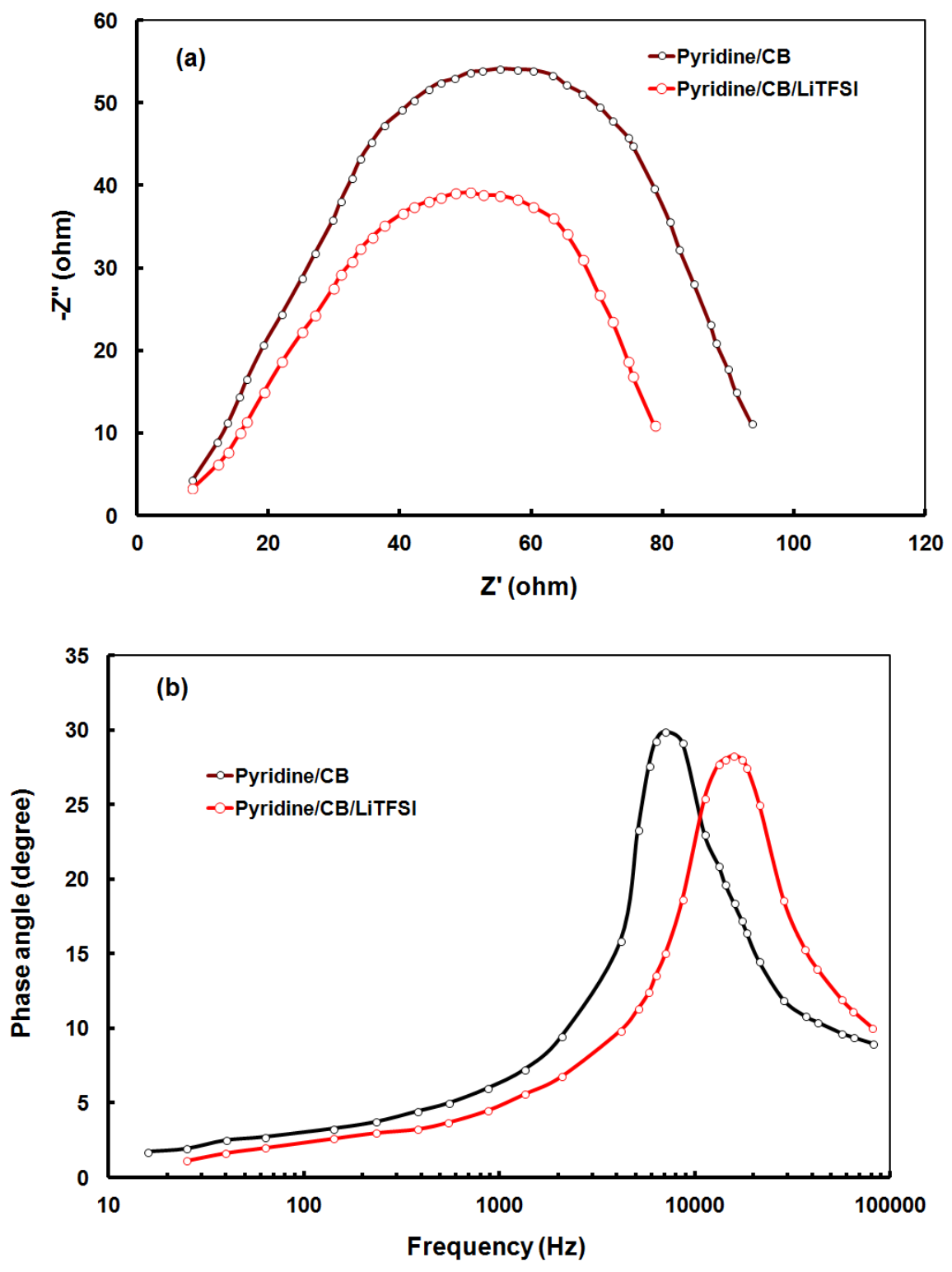

Figure 8 (a) Nyquist plots (b) Bode phase plots of the device based on $\mathbf{1 b}: \mathrm{PC}_{71} \mathrm{BM}$ (Pyridine/CB) without or with LiTFSI at $0 \mathrm{~V}$ with frequency ranging from $10 \mathrm{~Hz}$ to $0.1 \mathrm{MHz}$ 


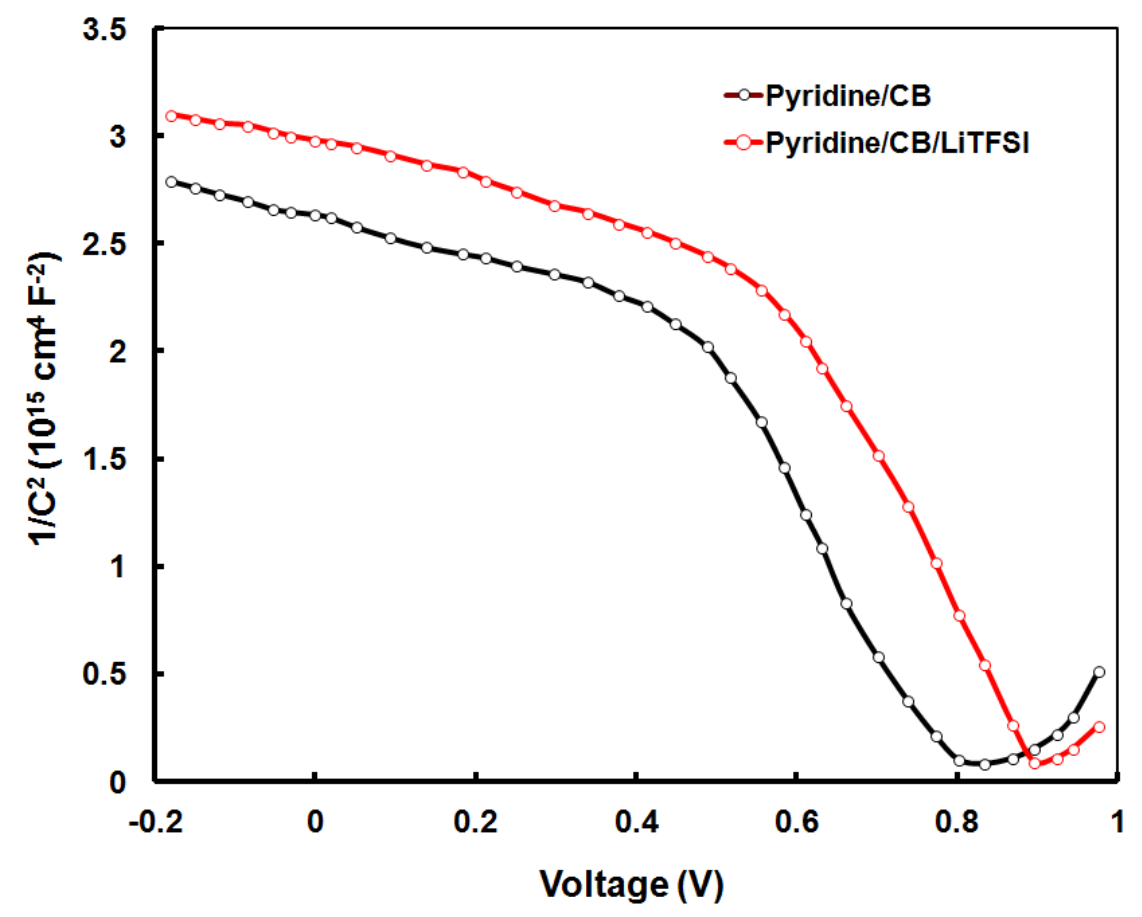

Figure 9 Mott-Schottky plots of the devices based on $\mathbf{1 b}: \mathrm{PC}_{71} \mathrm{BM}$ (pyridine/CB) with and without Li-TFSI.

\section{TOC}
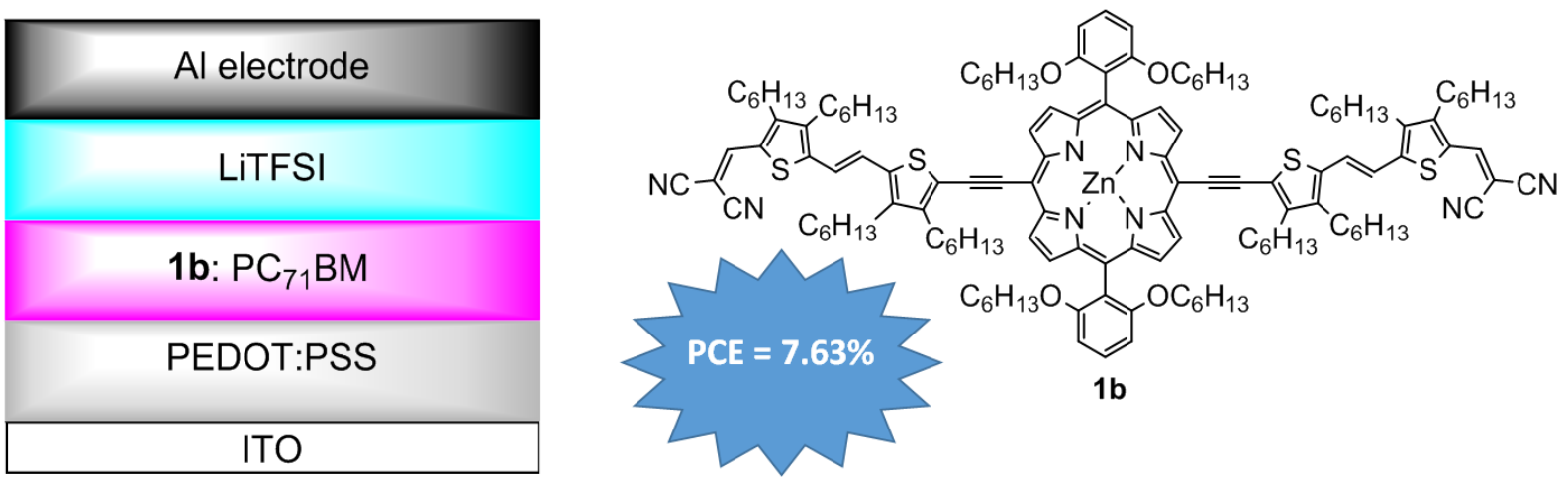